\title{
Sprawozdanie
}

\section{Konferencja naukowa „Idea wolności i niezależności w państwie demokratycznym - problemy ustrojowe", Jasionka k. Rzeszowa, 13-14 maja 2016 r.}

W dniach 13-14 maja 2016 r. w hotelu Ostoya, w Jasionce k. Rzeszowa odbyła się konferencja naukowa poświęcona problematyce idei wolności i niezależności w państwie demokratycznym. Konferencja w założeniu organizatorów - pracowników Katedry Instytucji Prawnych i Praw Człowieka WPiA UR - była uczczeniem i podziękowaniem za 40 lat pracy akademickiej Pani Profesor Haliny Zięby-Załuckiej.

Z okazji tego znakomitego jubileuszu w wydarzeniu wzięli udział wybitni konstytucjonaliści z wielu ośrodków uniwersyteckich w Polsce, a także przedstawiciele sądownictwa, prokuratury i organów kontroli państwa. Swoją obecnością wydarzenie uświetnili: prof. dr hab. J. Sobczak (SSN), prof. dr hab. E. Ura (SSO w Rzeszowie), dr G. Artymiak (SSO w Rzeszowie), dr M. Sztorc (SSO w Rzeszowie), G. Białowąs (prokurator Prokuratury Regionalnej), J. Woźnik (Prokurator Okręgowy w Tarnobrzegu), Ł. Harpula (p.o. Prokuratora Okręgowy w Rzeszowie), A. Korczowska (prokurator Prokuratury Rejonowej w Rzeszowie del. do Prokuratury Okręgowej w Rzeszowie), I. Czarnecka - prokurator Prokuratury Rejonowej w Mielcu oraz S. Różański (Przewodniczący Rady Izby Komorniczej), W. Motyka (Dyrektor Delegatury NIK w Rzeszowie) i dr J. Mazur (radca Prezesa NIK).

Konferencję otworzyła i uroczyście powitała szacowne grono gości Pani Prof. dr hab. H. Zięba-Załucka. W dalszej kolejności przemawiali: Jego Ma- 
gnificencja Rektor UR, prof. dr hab. S. Czopek oraz Dziekan WPiA UR prof. dr hab. S. Sagan składając podziękowania oraz życzenia pomyślności Jubilatce.

Po uroczystym otwarciu konferencji rozpoczęto obrady w ramach dwóch sesji merytorycznych. Sesji pierwszej przewodniczył prof. dr hab. S. Sagan, referaty wygłosili zaś na temat: wolności, niezależność i demokracji jako przesłanki członkostwa państwa w Radzie Europy - prof. zw. dr hab. Jerzy Jaskiernia (UJK w Kielcach); idei wolności i niezależności a przyczyn i kierunków zmian Konstytucji RP - prof. nadzw. dr hab. Andrzej Bisztyga (UZ); prawa do samostanowienia wobec koncepcji suwerenności - prof. zw. dr hab. J. Sobczak (SWPS Uniwersytet Humanistycznospołeczny); idei praw, wolności i bezpieczeństwa pracy i służby w RP - prof. nadzw. dr hab. M. Liwo (WSIiZ w Rzeszowie); wolność jednostki w Konstytucji Rzeczypospolitej Polskiej z 2 kwietnia 1997 r., jej definicji oraz potocznych intuicji - dr A. Biłgorajski (UŚ).

Sesji drugiej przewodniczył prof. nadzw. dr hab. Andrzej Bisztyga. Tematy referatów ogniskowały się wokół problematyki niezależności władzy sądowniczej (dr M. Haczkowska z Politechniki Opolskiej wygłosiła prelekcje mającą charakter rozważań teoretyczno - prawnych nt. niezależności władzy sądowniczej stawiając pytanie o realność czy też iluzoryczność owej niezależności), funkcjonowania sądownictwa konstytucyjnego jako warunku zabezpieczenia wolności i praw jednostek (wspomniane zagadnienie referował dr R. Balicki w UWr w wystąpieniu zatytułowanym Po co obywatelom sąd konstytucyjny?). $\mathrm{W}$ wypowiedziach prelegentów powrócił także wątek wiodący sesji pierwszej tj. kwestia rozumienia idei wolności. Należy wspomnieć w tym miejscu referat dra Ł. Pikuły (UJK w Kielcach) Idea wolności $w$ filozofii prawa Rudolfa Stammlera. Problem granic wolności słowa w kontekście art. $135 \$ 2$ k.k., penalizującego publiczne znieważenie Prezydenta RP, przedstawiła dr B. Stępień-Załucka (UR). Prelegentka scharakteryzowała rozwiązania prawne przyjętej w tożsamej materii w różnych krajach Europy Zachodniej, poddała również w wątpliwość zasadność polskiej regulacji w przyjętym zakresie. Dwie pierwsze sesje tematyczne zamknęła krótka dyskusja.

Przewodnictwo sesji trzeciej zostało powierzone prof. nadzw. dr hab. Bogusławowi Szmulikowi. W sesji tej wygłoszonych zostało pięć referatów. Re- 
ferat otwierający, dotyczący dwóch kwestii: po pierwsze sposobu wykonania przez ustawodawcę wyroku Trybunału Konstytucyjnego z 30 lipca 2014 r., sygn. K 23/11 (nadmienić należy, że wyrok dotyczy przepisów przyznających zbyt szerokie uprawnienia w zakresie kontroli operacyjnej policji, straży granicznej oraz służbom specjalnym) oraz po drugie oddziaływania sposobu wykonania wspomnianego wyroku na sposób realizacji konstytucyjnego prawa do wolności wygłosił prof. nadzw. dr hab. J. Paśnik (Akademia Humanistyczna im. A. Gieysztora w Pułtusku). W kolejnym wystąpieniu prof. zw. dr hab. Anna Łabno (UŚ) scharakteryzowała instytucjonalne granice wolności. W sesji trzeciej, dwa referaty bliskie sobie tematycznie, poświęcone zostały zagadnieniu statusu sędziego z uwzględnieniem konstytucyjnej zasady niezawisłości sędziowskiej i jej gwarancji. Głoszącymi byli dr J. Michalska (UZ) oraz mgr W. Kopczyński (UWM).

Wartym zauważenia pozostaje także referat dr D. Ossowskiej-Salamonowicz (UWM), w którym prelegentka odniosła się do kształtującego się na naszych oczach nowego aspektu prawa do prywatności, mianowicie prawa do bycia zapomnianym. Na konieczność zagwarantowania prawa do bycia zapomnianym - o czym wspomniała dr Ossowska Salamonowicz - zwrócił uwagę Trybunał Sprawiedliwości UE w wyroku z 13.05.2014 r. w sprawie C-131/12, Google Spain SL i Google Inc. przeciwko Agencia Española de Protección de Datos (AEPD) i Mario Costeja González. Prelegentka częściowo krytykując wyrok Trybunału zwróciła uwagę na konieczność zagwarantowania także „prawa do pamięci”.

Referat zamykający sesję trzecią wygłoszony został przez dra M. Śladkowskiego (UŚ), dotyczył problematyki przymusowego doprowadzenia dłużnika w postępowaniu o wyjawienie majątku, z uwzględnieniem aspektu konstytucyjnej zasady wolności.

W sesji czwartej zaprezentowane zostały referaty o zróżnicowanej tematyce. Dr J. Szukalski z Wyższej Szkoły Stosunków Międzynarodowych i Komunikacji Społecznej w Chełmie scharakteryzował instytucję Pełnomocnika Olij Madżlisu ds. Praw Człowieka w Uzbekistanie, mgr P. Króliczek (UŚ) wygłosił prelekcję nt. procedury rozpoznawania skarg i wniosków w postępowaniu przed Trybunałem Konstytucyjnym w kontekście ochrony praw i wolności jednostki, dr P. Kapusta (UZ) odniósł się do zagadnienia wolności związkowych w Konstytucji RP, mgr Natalie Fox podjęła kwestię roli 
sądu w postępowaniu w przedmiocie odpowiedzialności zawodowej lekarza w świetle konstytucyjnego prawa do sądu i na zakończenie dr K. Kozłowski (UJ) poruszył zagadnienie niezależności samorządu terytorialnego w świetle postanowień Konstytucji RP oraz Europejskiej Karty Samorządu Terytorialnego. Sesje tematyczne zamknęła dyskusja.

Owocem niniejszej konferencji będzie wydana nakładem Wydawnictwa Uniwersytetu Rzeszowskiego księga jubileuszowa upamiętniająca 40-lecie pracy akademickiej prof. zw. dr hab. Haliny Zięby-Załuckiej.

Joanna Uliasz Uniwersytet Rzeszowski 